Eric Holzenberg

\title{
Bridging the Gap: Education and Special Collections-The 46th RBMS Preconference
}

LIKE MOST OF THEIR COLLEAGUES in other branches of the profession, special collections librarians often act as teachers, informally with individual users or formally as leaders of classes. But because of the preservation and security needs of the rare books and manuscripts under their care, special collections librarians must take on the additional roles of interpreter, impresario, advocate, and cheerleader. Fragile and valuable materials not browsable by the casual user must be showcased and interpreted through exhibitions and catalogs; faculty and students must be proselytized about the value of special collections in the curriculum; library and university administrations must be petitioned for a fair share of budget monies; donors must be told how their gift will (or will not) fit into the context of existing collections; new constituencies must be identified and reached to support diversity among users and donors; and grant agencies must be convinced as to the quality and uniqueness of our collections. Funding, collection development, status within (and beyond) the institution, and fully realized use of these collections all depend on how skillful special collections librarians are at educating these various constituencies.

But many of the skills needed to reach these constituencies-fundraising, exhibition design and practice, donor relations - cannot be acquired within the context of a two-year master's program, and many of those that can be taught, such as descriptive bibliography and the history of the book, to name just two, are seldom addressed in library school curricula increasingly—and perhaps inevitably—dominated by courses on information science and the manipulation of the digital universe. Faced with an increasingly complex set of professional requirements on the one hand and a shrinking pool of formal educational opportunities on the other, those young professionals hoping to make a career in rare books and special collections must exercise a degree of self-reliance, commitment, and imagination unmatched in other fields of librarianship. And while new and aspiring professionals find that it takes all the running they can do to stay abreast of the needs of rare books and spe- 
cial collections librarianship, administrators of these collections are justly concerned about the quality and quantity of new librarians in line to succeed them.

Building on recent self-examination and fact-finding exercises such as the ARL White Paper on Education and Training for Careers in Special Collections, ${ }^{1}$ the nationwide $A^{\star}$ CENSUS survey of the archival profession, ${ }^{2}$ and the joint New York Public Library-British Library invitational meeting on 21st Century Curatorship, ${ }^{3}$ as well as discussions about core competencies for special collections librarianship taking place in the Rare Books and Manuscripts Section of ACRL/ALA and elsewhere, ${ }^{4}$ the organizers of the 2005 RBMS Preconference decided to collect and distill these and bring them to the profession's great annual gathering for discussion. Held June 21-24 in St. Louis and entitled "Bridging the Gap: Education and Special Collections," the goals of the 46th annual RBMS Preconference were to lay out the many ways in which special collections librarians act as educators; to identify the skills needed to play those roles; to assess the shrinking opportunities for acquiring them; and to address how to meet the profession's expanding needs for additional skill sets. The objectives of the preconference included providing up-to-date information about methods, techniques, and strategies in special collections librarianship; engaging attendees in discussion of issues relating the evolving profile of special collections in a digital world; and setting an agenda for the development of specialized continuing education for current and future generations of special collections librarians.

Attempts to address these questions were portioned thematically across five plenary sessions.

In laying a foundation for discussion, keynote speaker Deirdre Stam (Palmer Library School, Long Island University) adroitly outlined not only the conference's metaphorical bridge, but also the travelers who cross it, the on-and-off ramps leading to and from it, and the chasm it was attempting to span. In doing so, she established a leitmotif for the conference in her use of the term pizzazz to describe one kind of excellence in rare book librarianship.

Suzy Taraba (Wesleyan University) gave an extended and thoughtful introduction to the second plenary session, which dealt with issues of outreach and scholarly use

1. Alice Schreyer, "Education and Training Careers in Special Collections: A White Paper Prepared for the Association of Research Libraries Task Force" (ARL: November 2004). Available online at http:// www.arl.org/collect/spcoll/SCTF.ED.pdf.

2. See http://www.archivists.org/a-census/index.asp.

3. See http://www.nypl.org/research/curator/.

4. See http://www.rbms.nd.edu/committees/task_force/core_competencies_questionnaire.shtml for the results of such conversations within RBMS. 
of special collections. Stephen Escar Smith (Texas A\&M University) mused on the role of the librarian in the teaching and interpretation of rare books and manuscripts, whereas Margaret Mitchell (University of Chicago) tackled-with extraordinary pizzazz - the crucial role of the scholar in developing dynamic presentations using special collections materials.

The third plenary session, which was sponsored by the Bibliographical Society of America and moderated by Daniel Slive (William Reese Co.), summarized the state of educational opportunities for special collections librarians in the United States. Alice Schreyer (University of Chicago) summarized the work being done in identifying core competencies for special collections librarianship as a whole, and Beth Yakel (University of Michigan, Ann Arbor) concentrated on the findings of the $A^{\star} C E N S U S$ survey of the archival community. Bill Landis (California Digital Library, University of California) ended the session with a thoughtful talk that used the device of the "persona" to muse on the skills and educational background necessary for librarians in the year 2030.

The fourth plenary session was given over to a discussion of the state of special collections librarianship abroad. Moderated by program planning chair Eric Holzenberg (The Grolier Club of New York), the session opened with an overview by Patricia Fleming (University of Toronto) of special collections library education in Canada. Papers by François Dupuigrenet Desroussilles (Ecole Nationale Supérieure des Sciences de l'Information et des Bibliothèques, Lyon) and Mirjam Foot (University College, London) provided valuable contrasting viewpoints from France and the United Kingdom, respectively. Although M. Dupuigrenet Desroussilles was unfortunately prevented from being physically present at the session, his concise and informative talk was complemented, even enhanced, by the "dramatic reading" given by Richard Noble (Brown University).

The profession expects RBMS preconferences to be enlightening, educational, and (with luck) entertaining. The final plenary session of the preconference was all these by turns, but the 230-odd attendees also found themselves on occasion deeply moved. The presentation given by Mark Dimunation (Library of Congress) titled "Red Wine and White Carpets: What We Didn't Learn in Library School; or, When the Dog and Pony Show Goes Bad" moved deftly from humor to insight to strong emotion in a way that had the audience on its feet in a standing ovation. This almost unheard-of occurrence was followed by another, similar outpouring of approval for Terry Belanger's thoughtful summation; not many preconferences have ended on such a high note.

Undoubtedly, the attendees were responding not just to the plenary sessions, but also to the strong and well-chosen roster of seminars organized by Elizabeth 
Johnson (Lilly Library, Indiana University) and her committee, the thought-provoking short papers, the workshops, and, of course, the stellar performance of the St. Louis local arrangements committee. That committee was headed by Ann Posega (Washington University), and the success of the preconference owes a great deal to her hard work and her success in marshalling the really extraordinary generosity of Washington University. The organizers are equally grateful to John Neal Hoover and the St. Louis Mercantile Library, which not only provided one of the more lavish evenings of entertainment ever enjoyed by the Rare Books and Manuscripts Section, but also donated funds to make possible this expanded issue of RBM. Finally, I would like to thank past RBMS chair Elaine Smyth for contributing her unfailing support, sound advice, and intelligent criticism to the process of planning the RBMS preconference.

\section{Elegant Solutions for Preservation}

\section{Call for a complate cataich}

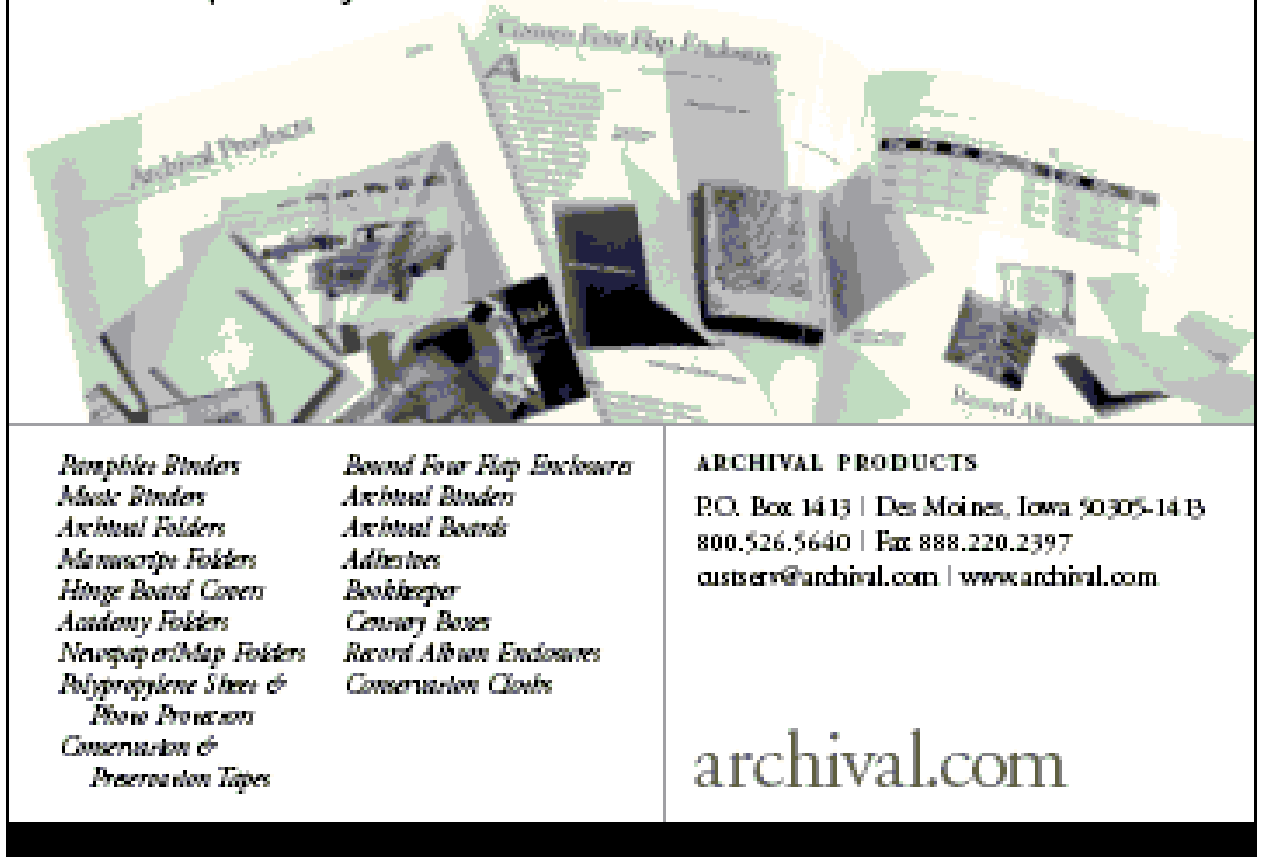

